\title{
Two Components in a Molecule: Highly Efficient and Thermally Robust Catalytic System for $\mathrm{CO}_{2}$ /Epoxide Copolymerization
}

\author{
Eun Kyung Noh, Sung Jae Na, Sujith S, Sang-Wook Kim, and Bun Yeoul Lee* \\ Department of Molecular Science and Technology, Ajou University, Suwon 443-749 Korea
}

\section{Supporting Information}

General Remarks. All manipulations were performed under an inert atmosphere using standard glove box and Schlenk techniques. THF and $\mathrm{C}_{6} \mathrm{D}_{6}$ were distilled from benzophenone ketyl. Ethanol was dried by the literature method by using sodium and diethyl phthalate (Armarego, W. L. F.; Perrin, D. D.; Purification of Laboratory Chemicals 4th Ed, Butterworth-Heinemann: Singapore, 1996; p 209). $\mathrm{CH}_{3} \mathrm{CN}, \mathrm{CH}_{2} \mathrm{Cl}_{2}, \mathrm{CDCl}_{3}$, and $\mathrm{CCl}_{4}$ were purified by stirring over $\mathrm{CaH}_{2}$ for 1 day and were transferred under vacuum to a reservoir. The $\mathrm{CO}_{2}$ gas $(99.99 \%)$ was purified by passing through a tank containing molecular sieves. Propylene oxide (PO) was purified by stirring over $\mathrm{CaH}_{2}$ for several days and it was transferred under vacuum to a reservoir. The ${ }^{1} \mathrm{H}$ NMR (400 MHz), ${ }^{13} \mathrm{C}$ NMR (100 MHz) and ${ }^{31} \mathrm{P}$ NMR (162 MHz) spectra were recorded on a Varian Mercury plus 400. The ${ }^{31} \mathrm{P}$ NMR spectra were calibrated and reported downfield from external $\mathrm{PPh}_{3}$. Elemental analyses were carried out at the Analytical Center, Kyunghee University. Mass spectra were obtained on a Micromass VG Autospec. The relative molecular weights were measured in THF using the polystyrene standard on Waters Millennium GPC (gel permeation chromatograms). The absolute molecular weights were measured at $35{ }^{\circ} \mathrm{C}$ in chloroform with a flow rate of $1.0 \mathrm{~mL} / \mathrm{min}$ on Viscotec GPC system equipped with TDA 302 detector (RI, viscometer, and light scattering $\left(90^{\circ}\right)$ detectors) at Korea Polymer Testing and Research Institute. 
Synthesis of 4-bromo-2-tert-butylphenol: To a stirred solution of 2-tert-butylphenol (40.0 g, 266 mmol) in carbon disulfide $(50 \mathrm{~mL})$ was added a solution of bromine $(42.6 \mathrm{~g}, 266 \mathrm{mmol})$ in carbon disulfide $(15 \mathrm{~mL})$ through dropping funnel over a period of 2 hours at $0{ }^{\circ} \mathrm{C}$. The solution was stirred overnight at room temperature. Solvent was removed with a rotary evaporator to give a residue, which was distilled under vacuum $\left(65-68{ }^{\circ} \mathrm{C} / 0.3 \mathrm{mmHg}\right)$ to give colorless oil $(54.9 \mathrm{~g}, 90 \%)$.

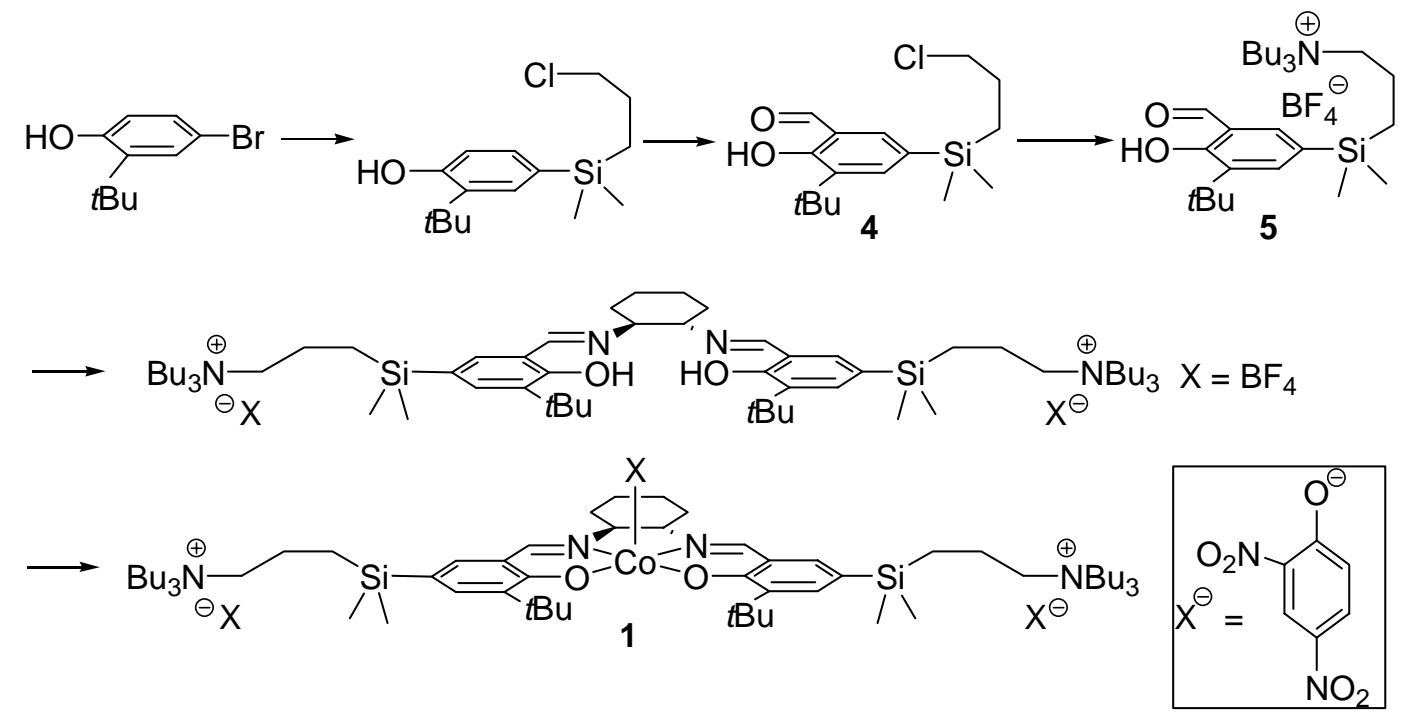

Compound 4. To a solution of 4-bromo-2-tert-butylphenol (2.70 g, $11.8 \mathrm{mmol})$ in THF $(100 \mathrm{~mL})$ was added dropwise a $t$-BuLi $(14.5 \mathrm{~g}, 1.7 \mathrm{M}$ in pentane, $37.7 \mathrm{mmol})$ at $-78{ }^{\circ} \mathrm{C}$. After the solution was stirred for 2 hours at $-78{ }^{\circ} \mathrm{C}$, chloro(3-chloropropyl)dimethylsilane (4.64 g, $27.1 \mathrm{mmol}$ ) was added. The solution was allowed to warm to room temperature and was stirred for another 2 hours. The reaction mixture was shaken with water $(150 \mathrm{~mL})$ for 4 hours and was transferred to a separatory funnel containing ethyl acetate $(100 \mathrm{~mL})$. The organic phase was collected, and the solvent was removed with a rotary evaporator to produce a residue which was purified by column chromatography on a silica gel eluting with ethyl acetate and hexane (v/v, 1:20) to obtain 2-tert-butyl-4-(3chloropropyl)dimethylsilylphenol (2.83 g, 84\%). IR (KBr): $3533(\mathrm{OH}) \mathrm{cm}^{-1} .{ }^{1} \mathrm{H}^{\mathrm{NMR}}\left(\mathrm{CDCl}_{3}\right): \delta 7.41$ (s, 1H,m-H), $7.22(\mathrm{dd}, J=7.6 \mathrm{~Hz}, 1.2 \mathrm{~Hz}, 1 \mathrm{H}, m-\mathrm{H}), 6.68(\mathrm{~d}, J=7.6 \mathrm{~Hz}, 1 \mathrm{H}, o-\mathrm{H}), 4.85(\mathrm{~s}, 1 \mathrm{H}, \mathrm{OH})$, $3.52\left(\mathrm{t}, J=7.2 \mathrm{~Hz}, 2 \mathrm{H}, \mathrm{CH}_{2} \mathrm{Cl}\right), 1.81\left(\mathrm{~m}, 2 \mathrm{H}, \mathrm{CH}_{2} \mathrm{CH}_{2} \mathrm{CH}_{2}\right), 1.45\left(\mathrm{~s}, 9 \mathrm{H}, t-\mathrm{BuCH}_{3}\right), 0.86\left(\mathrm{~m}, 2 \mathrm{H}, \mathrm{CH}_{2} \mathrm{Si}\right)$, $0.30\left(\mathrm{~s}, 6 \mathrm{H}, \mathrm{CH}_{3}\right)$ ppm. ${ }^{13} \mathrm{C}\left\{{ }^{1} \mathrm{H}\right\} \operatorname{NMR}\left(\mathrm{CDCl}_{3}\right): \delta 154.94,135.23,132.47,132.09,129.12,116.14$, 48.08, 34.67, 29.68, 27.81, 13.86, -2.72 ppm. HRMS (FAB): m/z calcd ([M] $\left.{ }^{+} \mathrm{C}_{15} \mathrm{H}_{25} \mathrm{ClOSi}\right) 284.1363$, 
found 284.1363 . The product $(2.72 \mathrm{~g}, 9.56 \mathrm{mmol})$ was dissolved in anhydrous THF $(180 \mathrm{~mL})$. Paraformaldehyde (1.15 g, $38.2 \mathrm{mmol})$, triethylamine (3.86 g, $38.7 \mathrm{mmol})$ and magnesium chloride (3.64 g, $38.2 \mathrm{mmol})$ were added under a nitrogen atmosphere. After the reaction mixture was heated to reflux for 3 hours, the solvent was removed with a rotary evaporator. Ethyl acetate $(150 \mathrm{~mL})$ and water (200 $\mathrm{mL}$ ) was added to the residue, and the organic phase was collected. The removal of solvent with a rotary evaporator produced a residue which was purified by column chromatography on a silica gel eluting with ethyl acetate and hexane (v/v, 1:20). Yield was $2.15 \mathrm{~g}(72 \%) .{ }^{1} \mathrm{H} \mathrm{NMR}\left(\mathrm{CDCl}_{3}\right): \delta 11.87(\mathrm{~s}$, 1H, OH), $9.91(\mathrm{~s}, 1 \mathrm{H}, \mathrm{CHO}), 7.64(\mathrm{~d}, J=1.6 \mathrm{~Hz}, 1 \mathrm{H}, m-\mathrm{H}), 7.53(\mathrm{~d}, J=1.6 \mathrm{~Hz}, 1 \mathrm{H}, m-\mathrm{H}), 3.53(\mathrm{t}, J=$ $\left.7.2 \mathrm{~Hz}, 2 \mathrm{H}, \mathrm{CH}_{2} \mathrm{Cl}\right), 1.81\left(\mathrm{~m}, 2 \mathrm{H}, \mathrm{CH}_{2}\right), 1.46\left(\mathrm{~s}, 9 \mathrm{H}, \mathrm{CH}_{3}\right), 0.91\left(\mathrm{~m}, 2 \mathrm{H}, \mathrm{CH}_{2} \mathrm{Si}\right), 0.35\left(\mathrm{~s}, 6 \mathrm{H}, \mathrm{CH}_{3}\right) \mathrm{ppm}$. ${ }^{13} \mathrm{C}\left\{{ }^{1} \mathrm{H}\right\} \mathrm{NMR}\left(\mathrm{CDCl}_{3}\right): \delta 197.14,161.68,138.35,137.76,137.20,127.93,120.34,47.85,34.92,29.27$, 27.61, 13.49, -2.90 ppm. HRMS (FAB): $\mathrm{m} / \mathrm{z}$ calcd ([M+H] $\left.]^{+} \mathrm{C}_{16} \mathrm{H}_{26} \mathrm{ClO}_{2} \mathrm{Si}\right)$ 313.1391, found 313.1391.

Compound $5\left(\mathbf{X}=\mathbf{B F}_{4}\right)$. Compound $4(1.00 \mathrm{~g}, 3.20 \mathrm{mmol})$, tributylamine $(0.89 \mathrm{~g}, 4.8 \mathrm{mmol})$, and sodium iodide $(0.72 \mathrm{~g}, 4.8 \mathrm{mmol})$ were dissolved in anhydrous acetonitrile $(5.0 \mathrm{~mL})$. After the mixture was stirred at $90{ }^{\circ} \mathrm{C}$ for 1 day, water $(10 \mathrm{~mL})$ and dichloromethane $(5 \mathrm{~mL})$ were added. The organic phase was separated, and the aqueous phase was extracted further with dichloromethane $(5 \mathrm{~mL} \times 3)$. After the combined organic phase was dried over anhydrous $\mathrm{MgSO}_{4}$, the solvent was removed with a rotary evaporator to yield an oily residue, which was washed with diethyl ether. The collected residue was dissolved in ethanol $(10 \mathrm{~mL})$, and then $\mathrm{AgBF}_{4}(0.686 \mathrm{~g}, 3.52 \mathrm{mmol})$ was added. After the slurry was stirred at room temperature for 1 hour, water $(10 \mathrm{~mL})$ and dichloromethane $(10 \mathrm{~mL})$ were added. The organic phase was separated, and the aqueous phase was extracted further with dichloromethane (5 $\mathrm{mL} \times 3$ ). The combined organic phase was dried over anhydrous $\mathrm{MgSO}_{4}$, and the solvent was removed to yield an oily residue which was purified by column chromatography on a silica gel eluting with dichloromethane and ethanol (v/v, 10:1). Yield was $0.96 \mathrm{~g}(56 \%) .{ }^{1} \mathrm{H}$ NMR $\left(\mathrm{CDCl}_{3}\right): \delta .11 .92(\mathrm{~s}, 1 \mathrm{H}$, $\mathrm{OH}), 9.96(\mathrm{~s}, 1 \mathrm{H}, \mathrm{CHO}), 7.67(\mathrm{~s}, 1 \mathrm{H}, \mathrm{m}-\mathrm{H}), 7.59(\mathrm{~s}, 1 \mathrm{H}, \mathrm{m}-\mathrm{H}), 3.24-3.08\left(\mathrm{~m}, 8 \mathrm{H}, \mathrm{NCH}_{2}\right), 1.79-1.50(\mathrm{~m}$, $\left.8 \mathrm{H}, \mathrm{CH}_{2}\right) 1.42\left(\mathrm{~s}, 9 \mathrm{H}, \mathrm{CH}_{3}\right), 1.43-1.30\left(\mathrm{~m}, 6 \mathrm{H}, \mathrm{CH}_{2}\right)$ 1.04-0.86 (m, 9H, $\left.\mathrm{CH}_{3}\right), 0.75(\mathrm{t}, J=8.4 \mathrm{~Hz}, 2 \mathrm{H}$, $\left.\mathrm{CH}_{2} \mathrm{Si}\right) 0.34\left(\mathrm{~s}, 6 \mathrm{H}, \mathrm{CH}_{3} \mathrm{Si}\right) \mathrm{ppm} .{ }^{13} \mathrm{C}\left\{{ }^{1} \mathrm{H}\right\} \mathrm{NMR}\left(\mathrm{CDCl}_{3}\right): \delta 198.12,161.73,138.39,138.08,137.18$, 
$127.04,120.49,61.10,58.29,34.90,29.25,23.75,19.59,16.69,13.59,12.23,-3.15$ ppm. HRMS (FAB): $\mathrm{m} / \mathrm{z}$ calcd $\left(\left[\mathrm{M}-\mathrm{BF}_{4}\right]^{+} \mathrm{C}_{28} \mathrm{H}_{52} \mathrm{NO}_{2} \mathrm{Si}\right)$ 462.3762, found 462.3767. Anal. Calc. $\left(\mathrm{C}_{28} \mathrm{H}_{52} \mathrm{BF}_{4} \mathrm{NO}_{2} \mathrm{Si}\right): \mathrm{C}$, 61.19; H, 9.54; N, $2.55 \%$. Found: C, 61.31; H, 9.21; N, $2.23 \%$.

Complex 1. A solution of $5(0.212 \mathrm{~g}, 0.386 \mathrm{mmol})$ and ( \pm -trans-1,2-diaminocyclohexane $(0.020 \mathrm{~g}$, $0.18 \mathrm{mmol})$ in ethanol $(2 \mathrm{~mL})$ was stirred overnight in the presence of molecular sieves. After removing the molecular sieves by filtration, the solvent was removed to obtain a yellow solid, which was purified by column chromatography on a silica gel eluting with dichloromethane and ethanol (v/v, 10:1) to give a "Salen"-type ligand (0.211 g, 93\%). IR (KBr): $3421(\mathrm{OH}), 1625(\mathrm{C}=\mathrm{N}) \mathrm{cm}^{-1} .{ }^{1} \mathrm{H}$ NMR $\left(\mathrm{CDCl}_{3}\right): \delta$ $14.16(\mathrm{~s}, 2 \mathrm{H}, \mathrm{OH}), 8.42(\mathrm{~s}, 2 \mathrm{H}, \mathrm{CH}=\mathrm{N}), 7.32(\mathrm{~s}, 2 \mathrm{H}, \mathrm{m}-\mathrm{H}), 7.21(\mathrm{~s}, 2 \mathrm{H}, \mathrm{m}-\mathrm{H}), 3.40(\mathrm{t}, J=4.0 \mathrm{~Hz}, 2 \mathrm{H}$, $\mathrm{CHN}), 3.11\left(\mathrm{t}, J=8.0 \mathrm{~Hz}, 16 \mathrm{H}, \mathrm{NCH}_{2}\right), 2.04-1.96\left(\mathrm{~m}, 2 \mathrm{H}\right.$, cyclohexyl- $\left.\mathrm{CH}_{2}\right), 1.92-1.87(\mathrm{~m}, 2 \mathrm{H}$, cyclohexyl- $\left.\mathrm{CH}_{2}\right), 1.74-1.68\left(\mathrm{~m}, 4 \mathrm{H}\right.$, cyclohexyl- $\left.\mathrm{CH}_{2}\right), 1.58-1.40\left(\mathrm{~m}, 16 \mathrm{H}, \mathrm{NCH}_{2} \mathrm{CH}_{2}\right), 1.41(\mathrm{~s}, 18 \mathrm{H}, t-$ $\left.\mathrm{BuCH}_{3}\right) 1.32$ (sextet, $\left.J=7.2 \mathrm{~Hz}, 12 \mathrm{H}, \mathrm{NCH}_{2} \mathrm{CH}_{2} \mathrm{CH}_{2}\right), 0.90\left(\mathrm{t}, J=7.6 \mathrm{~Hz}, 18 \mathrm{H}, \mathrm{CH}_{3}\right), 0.70(\mathrm{t}, J=8.0 \mathrm{~Hz}$, 4H, $\left.\mathrm{SiCH}_{2}\right), 0.26\left(\mathrm{~s}, 6 \mathrm{H}, \mathrm{SiCH}_{3}\right), 0.25\left(\mathrm{~s}, 6 \mathrm{H}, \mathrm{SiCH}_{3}\right) \mathrm{ppm} .{ }^{13} \mathrm{C}\left\{{ }^{1} \mathrm{H}\right\} \mathrm{NMR}\left(\mathrm{CDCl}_{3}\right): \delta 165.35,161.39$, $136.34,135.68,133.46,124.69,118.48,71.70,60.95,58.21,34.81,32.73,29.38,24.03,23.65,19.53$, 16.72, 13.54, 12.24, -2.94, -3.22 ppm. HRMS (FAB): $\mathrm{m} / \mathrm{z}$ calcd $\left(\left[\mathrm{M}-\mathrm{BF}_{4}\right]^{+} \mathrm{C}_{62} \mathrm{H}_{114} \mathrm{~N}_{4} \mathrm{O}_{2} \mathrm{Si}_{2} \mathrm{BF}_{4}\right)$ 1089.8504, found 1089.8521. Anal. Calc. $\left(\mathrm{C}_{62} \mathrm{H}_{114} \mathrm{~B}_{2} \mathrm{~F}_{8} \mathrm{~N}_{4} \mathrm{O}_{2} \mathrm{Si}_{2}\right): \mathrm{C}, 63.25 ; \mathrm{H}, 9.76 ; \mathrm{N}, 4.76 \%$. Found: C, 63.55; H, 9.49; N, $4.32 \%$. Cobalt(II)acetate (0.022 g, $0.13 \mathrm{mmol})$ and the ligand $(0.147 \mathrm{~g}, 0.125$ mmol) were dissolved in ethanol $(6 \mathrm{~mL})$ inside a glovebox. A red solid precipitated immediately. After stirring for 2 hours at room temperature, the solid was collected by filtration and was washed with ethanol $(2.0 \mathrm{~mL})$. The solid was dissolved in dichloromethane containing 2,4-dinitrophenol $(0.023 \mathrm{~g}$, $0.12 \mathrm{mmol}$ ). After the solution was stirred under oxygen for 1.5 hours, sodium 2,4-dinitrophenolate (0.051 g, $0.25 \mathrm{mmol})$ was added. The solution was stirred overnight at room temperature and was filtered over Celite. Removal of solvent gave a brown solid which was pure through the analysis of the ${ }^{1} \mathrm{H}$ and ${ }^{13} \mathrm{C}$ NMR spectra. ${ }^{1} \mathrm{H}$ NMR $\left(\right.$ dmso-d $\left._{6}\right): \delta 8.58\left(\mathrm{~d}, J=0.8 \mathrm{~Hz}, 3 \mathrm{H},\left(\mathrm{NO}_{2}\right)_{2} \mathrm{C}_{6} \mathrm{H}_{3} \mathrm{O}\right), 7.90(\mathrm{~s}, 2 \mathrm{H}$, $\mathrm{CH}=\mathrm{N}), 7.75\left(\mathrm{dd}, J=9.6,3.2 \mathrm{~Hz}, 3 \mathrm{H},\left(\mathrm{NO}_{2}\right)_{2} \mathrm{C}_{6} \mathrm{H}_{3} \mathrm{O}\right), 7.68(\mathrm{~s}, 2 \mathrm{H}, m-\mathrm{H}), 7.45(\mathrm{~s}, 2 \mathrm{H}, m-\mathrm{H}), 6.30(\mathrm{~d}, J=$ 9.6, 3H, $\left.\left(\mathrm{NO}_{2}\right)_{2} \mathrm{C}_{6} \mathrm{H}_{3} \mathrm{O}\right), 3.63-3.57$ (br, $2 \mathrm{H}$, cyclohexyl-CH) 3.23-3.12 (m, 12H, $\left.\mathrm{NCH}_{2}\right)$, 3.12-3.02 (m, 
4H, $\mathrm{NCH}_{2}$ ), 2.08-1.96 (br, 4H, cyclohexyl- $\left.\mathrm{CH}_{2}\right)$ 1.96-1.82 (br, 4H, cyclohexyl- $\left.\mathrm{CH}_{2}\right) 1.74\left(\mathrm{~s}, 18 \mathrm{H}, \mathrm{CH}_{3}\right)$ 1.70-1.52 (m, $16 \mathrm{H}, \mathrm{SiCH}_{2} \mathrm{CH}_{2}$ and butyl- $\left.\mathrm{CH}_{2}\right), 1.36-1.25\left(\mathrm{~m}, 12 \mathrm{H}\right.$, butyl- $\left.\mathrm{CH}_{2}\right) 0.92(\mathrm{t}, J=7.6 \mathrm{~Hz}, 18 \mathrm{H}$, $\left.\mathrm{CH}_{3}\right), 0.71\left(\mathrm{t}, J=8.0,4 \mathrm{H}, \mathrm{SiCH}_{2}\right) 0.30\left(\mathrm{~s}, 6 \mathrm{H}, \mathrm{SiCH}_{3}\right), 0.29\left(\mathrm{~s}, 6 \mathrm{H}, \mathrm{SiCH}_{3}\right) \mathrm{ppm} .{ }^{13} \mathrm{C}\left\{{ }^{1} \mathrm{H}\right\} \mathrm{NMR}(\mathrm{dmso}-$ $\left.\mathrm{d}_{6}\right): \delta 169.79,164.93,164.40,141.64,140.23,134.89,127.07,126.15,124.70,120.92,119.15,69.30$, $60.34,57.39,35.55,30.25,29.51,24.18,23.02,19.17,16.32,13.43,11.91,-2.66,-2.74$ ppm. HRMS (FAB): $\mathrm{m} / \mathrm{z}$ calcd $\left(\left[\mathrm{M}-2\left\{\left(\mathrm{NO}_{2}\right)_{2} \mathrm{C}_{6} \mathrm{H}_{3} \mathrm{O}\right\}\right]^{+} \mathrm{C}_{68} \mathrm{H}_{115} \mathrm{CoN}_{6} \mathrm{O}_{7} \mathrm{Si}_{2}\right)$ 1242.7687, found 1242.7698.

$\mathrm{CO}_{2} /$ (propylene oxide) copolymerization (Small Scale). Into a glassware which fits a bomb reactor $(50 \mathrm{~mL})$ were added, inside a glove box, the complex and propylene oxide $(10.0 \mathrm{~g}, 172 \mathrm{mmol})$. The bomb reactor was assembled and immersed in an oil bath whose temperature had been set at a given temperature. It was stirred for 15 minutes to allow temperature of the solution to reach the bath temperature. The $\mathrm{CO}_{2}$ gas was pressurized to 20 bar. As the polymerization proceeds, a pressure drop was observed. When the pressure drop reaches $\sim 3$ bar, the reaction was ceased by releasing the $\mathrm{CO}_{2}$ pressure. The viscous solution was poured into a flask containing methanol to give a white lump. After the lump was broken, it was stirred overnight over methanol. The collected white solid was dried under vacuum at $60{ }^{\circ} \mathrm{C}$ for several hours. The crude samples or the isolated polymers were dissolved in $\mathrm{CDCl}_{3}$ to do NMR studies. The ${ }^{1} \mathrm{H}$ and ${ }^{13} \mathrm{C}$ NMR spectra of a typical polymer are shown below. The GPC traces of the polymer exhibit a narrow bimodal shape, which might be attributed to the presence of more than one chain-growing unit in $\mathbf{1}$. When the polymerization time increases (entry 5), some tailoring in the low molecular-weight portion was observed in the GPC trace (See the GPC traces below). The polymer solution of $29 \%$ conversion (entry 5 ) is so viscous that it flows very slowly by gravity (see the picture shown below). In the expanded version of Table 1 below, additional information such as conversions, concentrations (weight\%) of the obtained polymerization solution, head to tail linkages determined by the ${ }^{13} \mathrm{C}$ NMR, carbonate linkages determined by ${ }^{1} \mathrm{H}$ NMR, and the absolute molecular weights determined on GPC equipped with RI, viscometer, and light scattering $\left(90^{\circ}\right)$ detectors are included, which are marked in blue. 
The molecular weights calculated from TON $((102 \times \mathrm{TON}) / 3)$ are deviated from the ones $\left(\mathrm{M}_{\mathrm{n}}\right)$ determined on GPC using the polystyrene standard with RI detector. The discrepancy is also observed in other studies for the (propylene oxide) $/ \mathrm{CO}_{2}$ copolymerization (for example, in reference 8 , Table 1 , entry 3, $84000\left(M_{n}\right.$ on GPC) versus 262000 (calculated); in reference 1(a), Table 1, entry 2, $20000\left(M_{n}\right.$ on GPC) versus 44000(calculated)). The molecular weights determined on GPC using the polystyrene standard are relative ones, not the absolute ones. So, the discrepancy might be natural. In the case of the rigid polymers such as polythiophenes, the relative molecular weights determined on GPC using the polystyrene standard were reported to be significantly higher than the real absolute molecular weights (Feast, W. J.; Tsibouklis, J.; Pouwer, K. L.; Groenendaal, L.; Meijer, E. W. Polymer 1996, 37, 5017.). The $\mathrm{PO} / \mathrm{CO}_{2}$ polymer is more flexible than the PS and, reversely, the relative molecular weight based on the PS standard might be smaller than the real absolute molecular weight. The absolute molecular weights were measured on Viscotec GPC system equipped with TDA 302 detector (RI, viscometer, and light scattering $\left(90^{\circ}\right)$ detectors) and they are tabulated in the expanded version of Table 1 below.

$\mathrm{CO}_{2} /$ (propylene oxide) copolymerization (100 g Scale). A bomb reactor (500 $\mathrm{mL}$ scale) equipped with a mechanical stirrer was evacuated at $70{ }^{\circ} \mathrm{C}$ for 3 hours. After the reactor was cooled to room temperature, propylene oxide $(180 \mathrm{~g})$ was charged with a cannula. A solution of $1(0.220 \mathrm{~g}, 0.138$ mmol) in propylene oxide ( $20 \mathrm{~g}$ ) was added with a syringe. Temperature was raised to $80{ }^{\circ} \mathrm{C}$ and $\mathrm{CO}_{2}$ gas was charged to 20 bar. As the polymerization proceeded, a rapid pressure drop was observed. Whenever the pressure dropped below 17 bar, additional $\mathrm{CO}_{2}$ gas was charged to 20 bar. After 5 hours, consumption of $\mathrm{CO}_{2}$ gas was significantly slow down and in six hours the stirring system was broken presumably due to the severe viscosity of the polymerization solution. After the $\mathrm{CO}_{2}$ pressure was released, methanol was added to the reactor. The polymer lump was transferred to a beaker $(1 \mathrm{~L})$ and it was manually broken to pieces which were stirred over methanol for 1 day. The polymer (116 g) was isolated by filtration and dried under vacuum (see the picture below). 
Table 1. $\mathrm{CO}_{2} /$ (Propylene oxide) Copolymerization Results ${ }^{a}$

\begin{tabular}{|c|c|c|c|c|c|c|c|c|c|c|c|c|}
\hline $\begin{array}{l}\text { Ent } \\
\text { ry }\end{array}$ & $\begin{array}{c}\text { Cat; } \\
{[\mathrm{PO}] /[\mathrm{Cat}]}\end{array}$ & $\begin{array}{c}\mathrm{T} \\
{ }^{\circ} \mathrm{C}\end{array}$ & $\mathrm{t}(\mathrm{h})$ & $\begin{array}{l}\mathrm{TOF}^{b} \\
\left(\mathrm{~h}^{-1}\right)\end{array}$ & $\mathrm{TON}^{b}$ & $\begin{array}{c}\text { Con } \\
\text { vers } \\
\text { ion } \\
(\%) \\
k\end{array}$ & $\begin{array}{c}\text { Conc } \\
\text { entrat } \\
\text { ion } \\
\mathrm{w} \%{ }^{l}\end{array}$ & $\begin{array}{l}\text { Select } \\
\text { ivity }^{c}\end{array}$ & $\begin{array}{l}\mathrm{M}_{\mathrm{n}}{ }^{d} \\
\times 10^{-3}\end{array}$ & $\mathrm{M}_{\mathrm{w}} / \mathrm{M}_{\mathrm{n}}{ }^{d}$ & $\begin{array}{c}\text { Head- } \\
\text { to- } \\
\text { Tail } \\
\text { linka } \\
\text { ge } \\
(\%)\end{array}$ & $\begin{array}{c}\text { Carbon } \\
\text { ate } \\
\text { linkage } \\
(\%)\end{array}$ \\
\hline 1 & $1 ; 25000$ & 50 & 7.0 & 650 & 4600 & 18 & 28 & 100 & $75(50)$ & $1.23(1.58)$ & 94 & $>99$ \\
\hline 2 & $\mathbf{1} ; 25000$ & 70 & $1.0^{m}$ & 2400 & 2400 & 9.6 & 16 & 94 & $61(69)$ & $1.19(1.12)$ & 92 & $>99$ \\
\hline 3 & $\mathbf{1} ; 25000$ & 80 & $1.0^{m}$ & 3300 & 3300 & 13 & 21 & 94 & $71(85)$ & $1.25(1.14)$ & 88 & $>99$ \\
\hline 4 & $\mathbf{1} ; 25000$ & 90 & $1.0^{m}$ & 3500 & 3500 & 14 & 22 & 90 & $80(92)$ & $1.32(1.16)$ & 86 & $>99$ \\
\hline 5 & $1 ; 50000$ & 80 & $4.5^{f}$ & 3200 & 14500 & 29 & 42 & 84 & $53(63)$ & $1.35(1.20)$ & 83 & $>99$ \\
\hline $6^{e}$ & $\mathbf{1} ; 25000$ & 80 & $6.0^{f}$ & 1400 & 8300 & 33 & 46 & 88 & $95(120)$ & $1.46(1.27)$ & 78 & $>99$ \\
\hline $7^{g}$ & $2 ; 25000$ & 80 & 1.0 & 0 & 0 & & & 0 & & & & \\
\hline $8^{h}$ & $2 ; 2000$ & 45 & 0.7 & 1400 & 980 & 49 & 63 & 97 & 26 & 1.01 & 89 & $>99$ \\
\hline 9 & $3 ; 25000$ & 80 & 3.0 & 370 & $1100^{i}$ & 4.4 & 7.5 & 60 & n.d. ${ }^{i}$ & n.d. & & \\
\hline $10^{j}$ & $3 ; 2000$ & 60 & 1.0 & 610 & 610 & 31 & 44 & 90 & 7 & 1.22 & & \\
\hline
\end{tabular}

${ }^{a}$ Polymerization condition: Propylene oxide $(10.0 \mathrm{~g}), \mathrm{CO}_{2}$ (initial pressure, 2.0 MPa). ${ }^{b}$ Calculated based on the weight of the isolated polymer not including the cyclic carbonate. ${ }^{c}$ Selectivity for the polycarbonate over the cyclic carbonate in unit of \% determined by the ${ }^{1} \mathrm{H}$ NMR spectroscopy of the crude product. ${ }^{d}$ Determined on GPC using the polystyrene standard (Values in the parentheses are the absolute molecular weights determined on GPC equipped with RI, viscometer, and light scattering $\left(90^{\circ}\right)$ detectors). ${ }^{e}$ Scale-up reaction: Propylene oxide $(200 \mathrm{~g}), \mathrm{CO}_{2}$ pressure $(2.0-1.7 \mathrm{MPa}) .{ }^{f}$ Enough time is given to maximize TON. ${ }^{g}$ Only the cyclic carbonate was obtained with TOF of $1950 \mathrm{~h}^{-1}$. ${ }^{h}$ Data from reference 1(a). ${ }^{i}$ Isolation of the polymer by precipitating in methanol was failed by nature of its low molecular weight, and the TOF and the TON were calculated from the ${ }^{1} \mathrm{H}$ NMR spectra of the crude product. ${ }^{j}$ Data from reference $8 .{ }^{k} 100 \times($ Mole of the reacted PO $) /($ mole of the charged PO). ${ }^{l} 100 \times($ Weight of the obtained polymer $) /[($ weight of the unreacted $\mathrm{PO})+($ weight of the obtained polymer)]. ${ }^{m}$ Reaction was quenched at the early stage to maximize TOF. 
$<$ Polymer solution of $29 \%$ conversion (entry 5) $>$

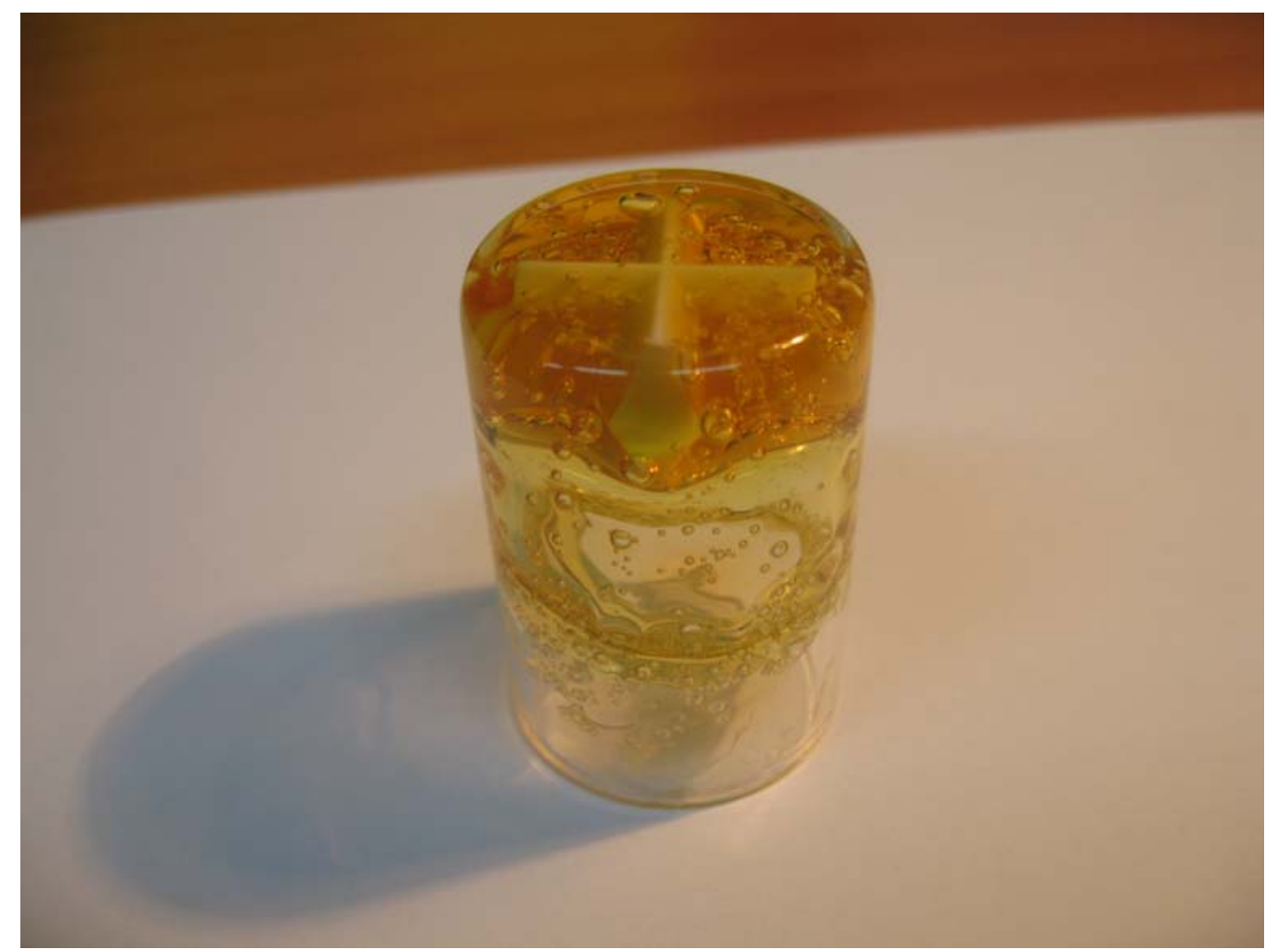

$<$ Isolated polymer prepared in $100 \mathrm{~g}$ scale (entry 6)>

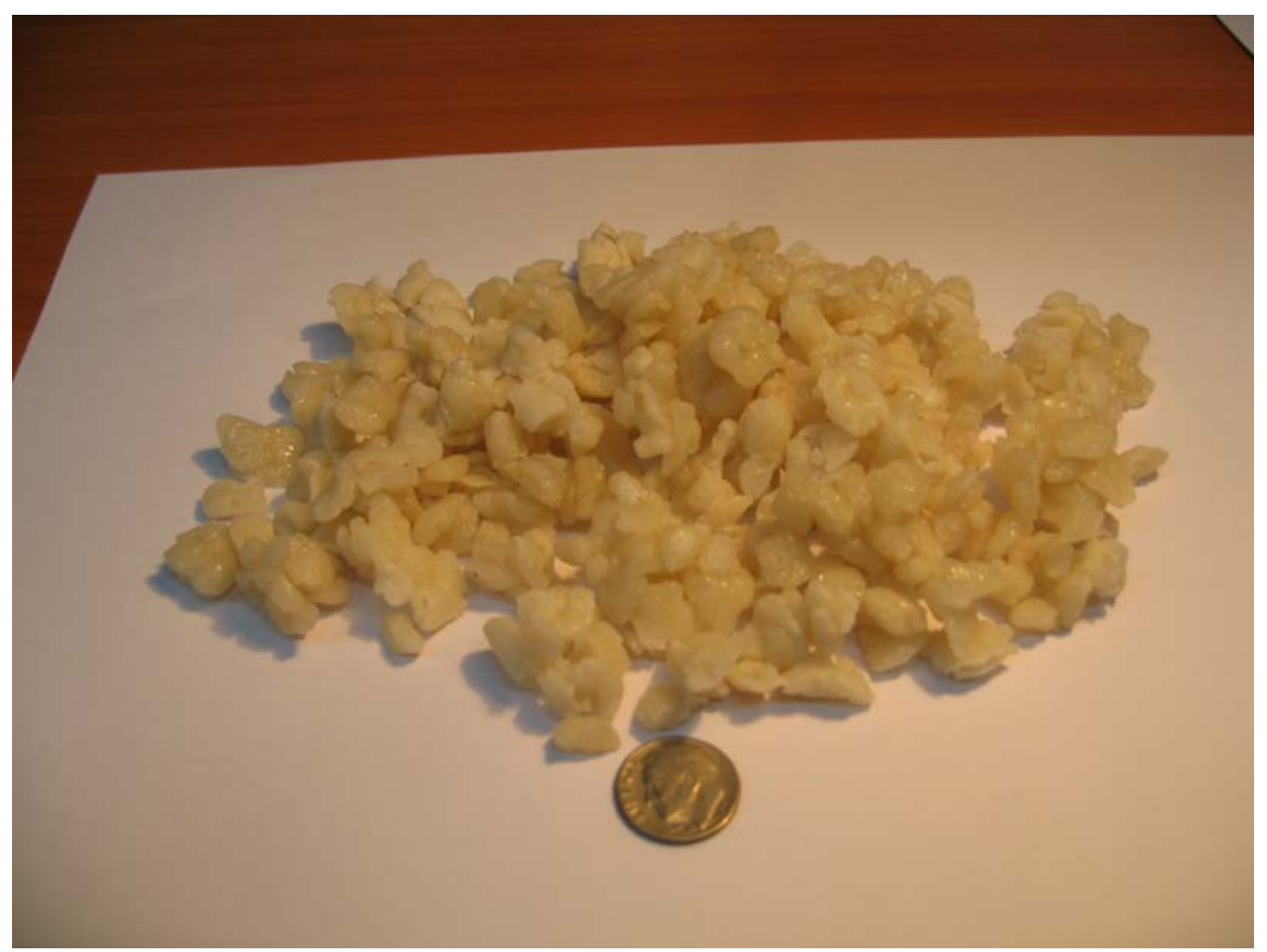


<The GPC trace of the copolymer of entry 3>

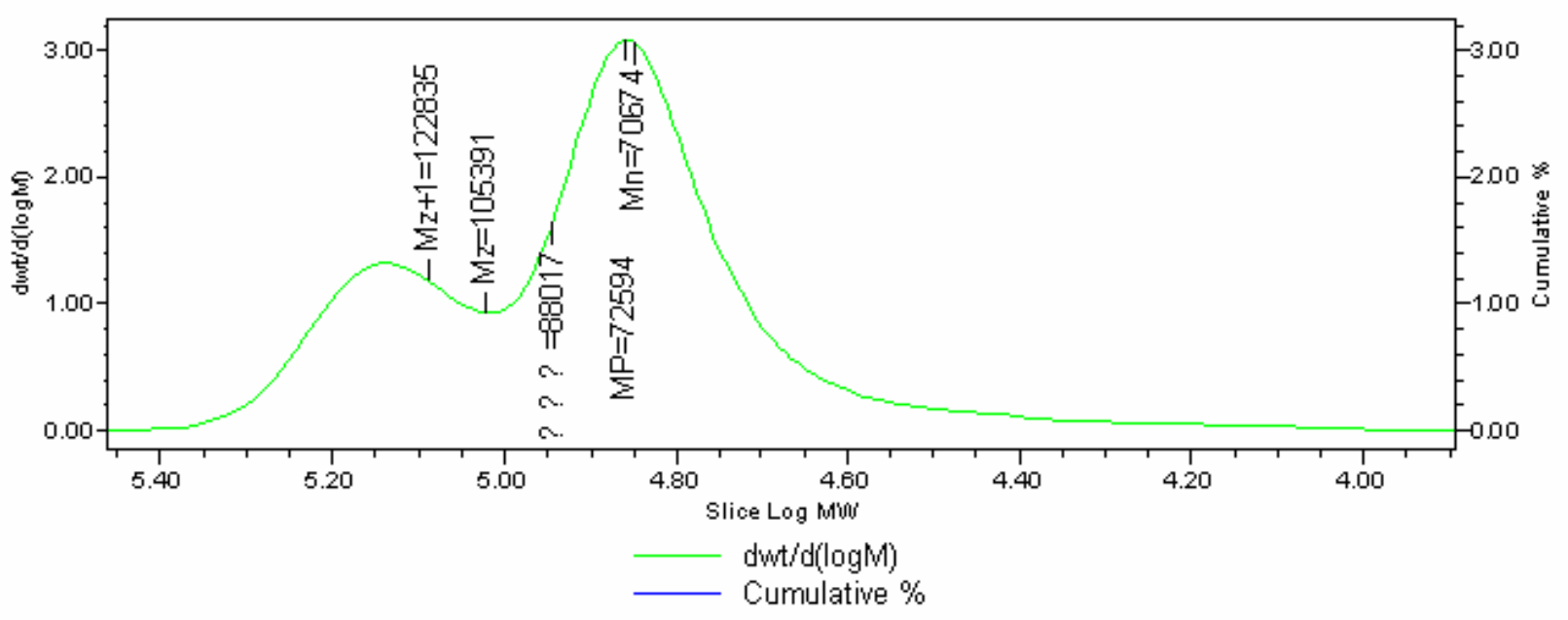

<The GPC trace of the copolymer of entry 5>

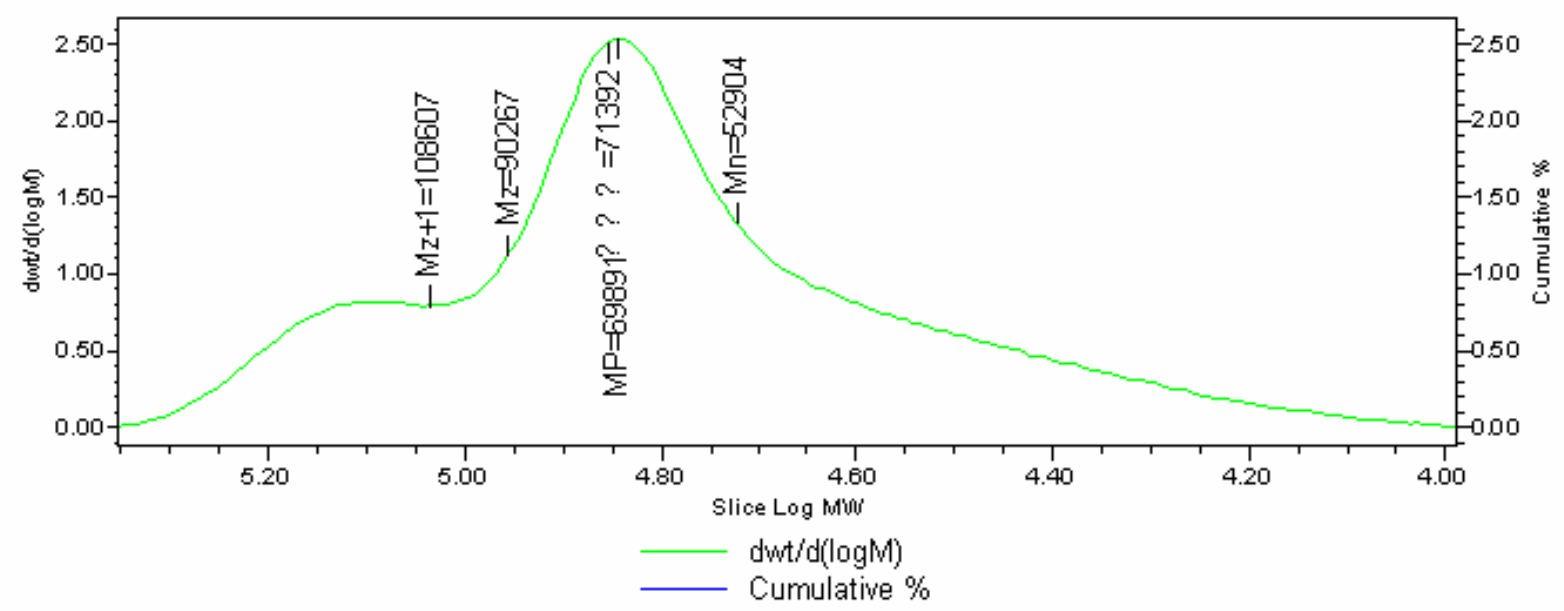


$<^{1}$ H NMR spectrum of the crude product prepared on the conditions of entry $3>$

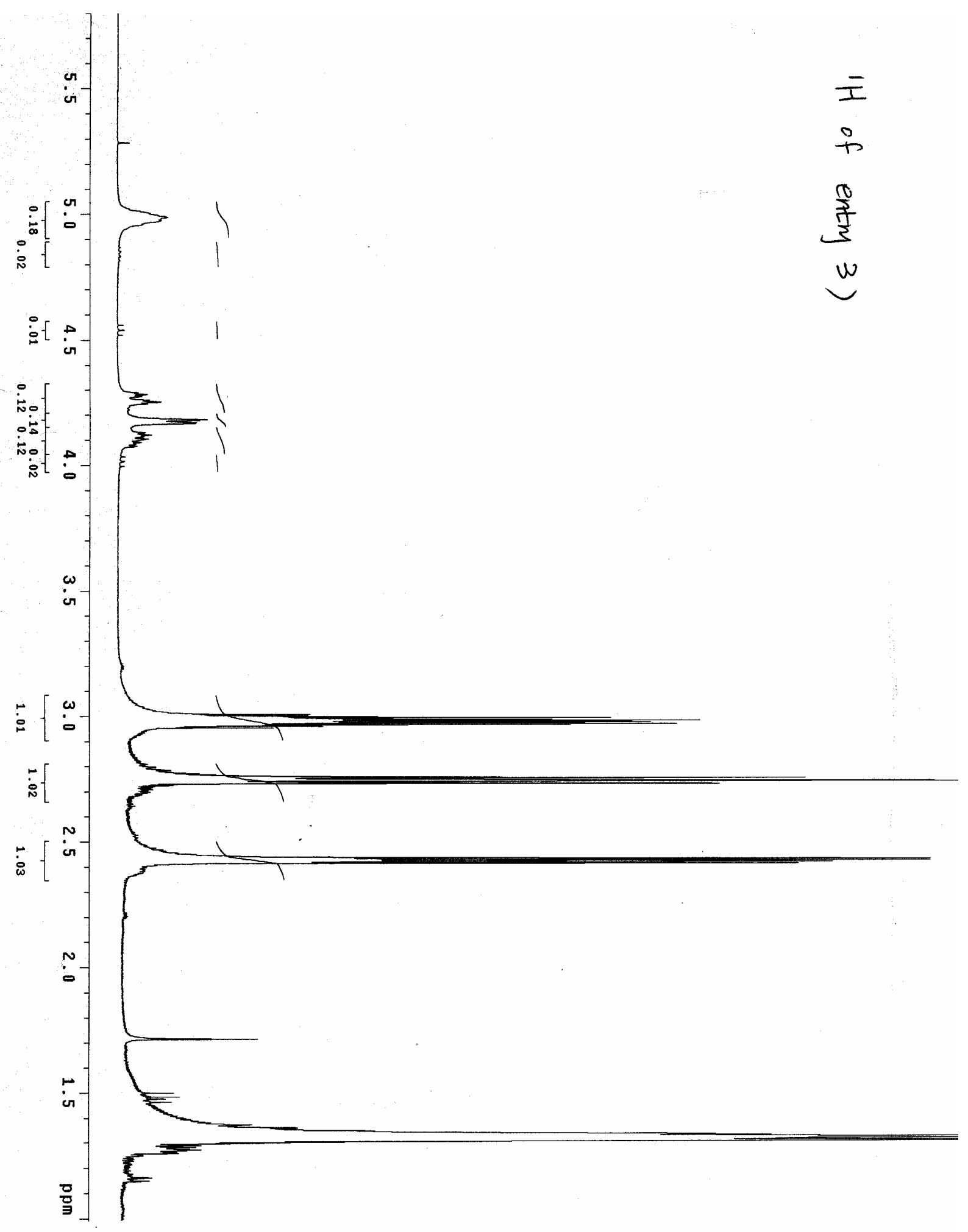


$<{ }^{13} \mathrm{C}$ NMR spectrum of polymer of entry $5>$

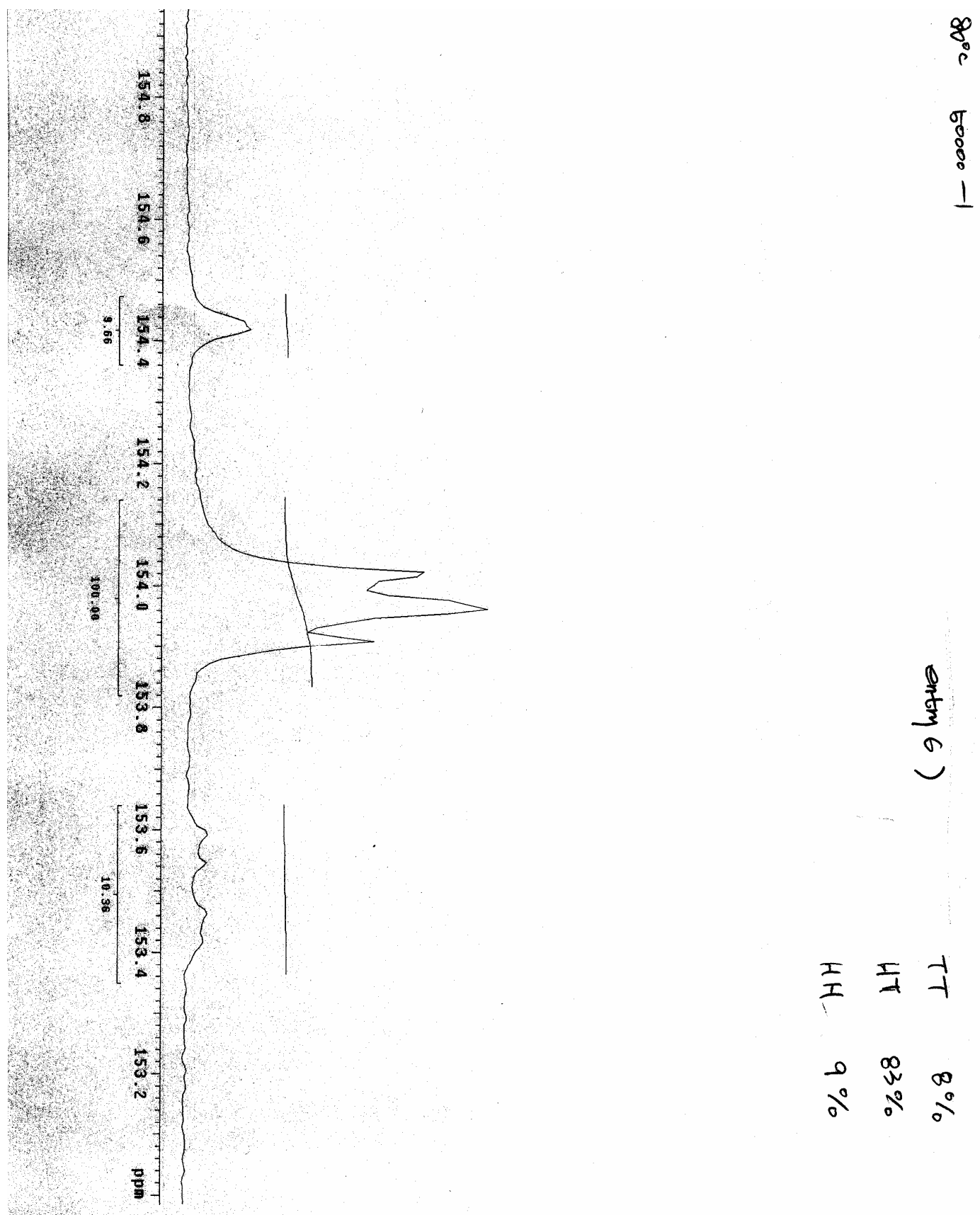


$<^{1}$ H NMR spectrum of $4>$

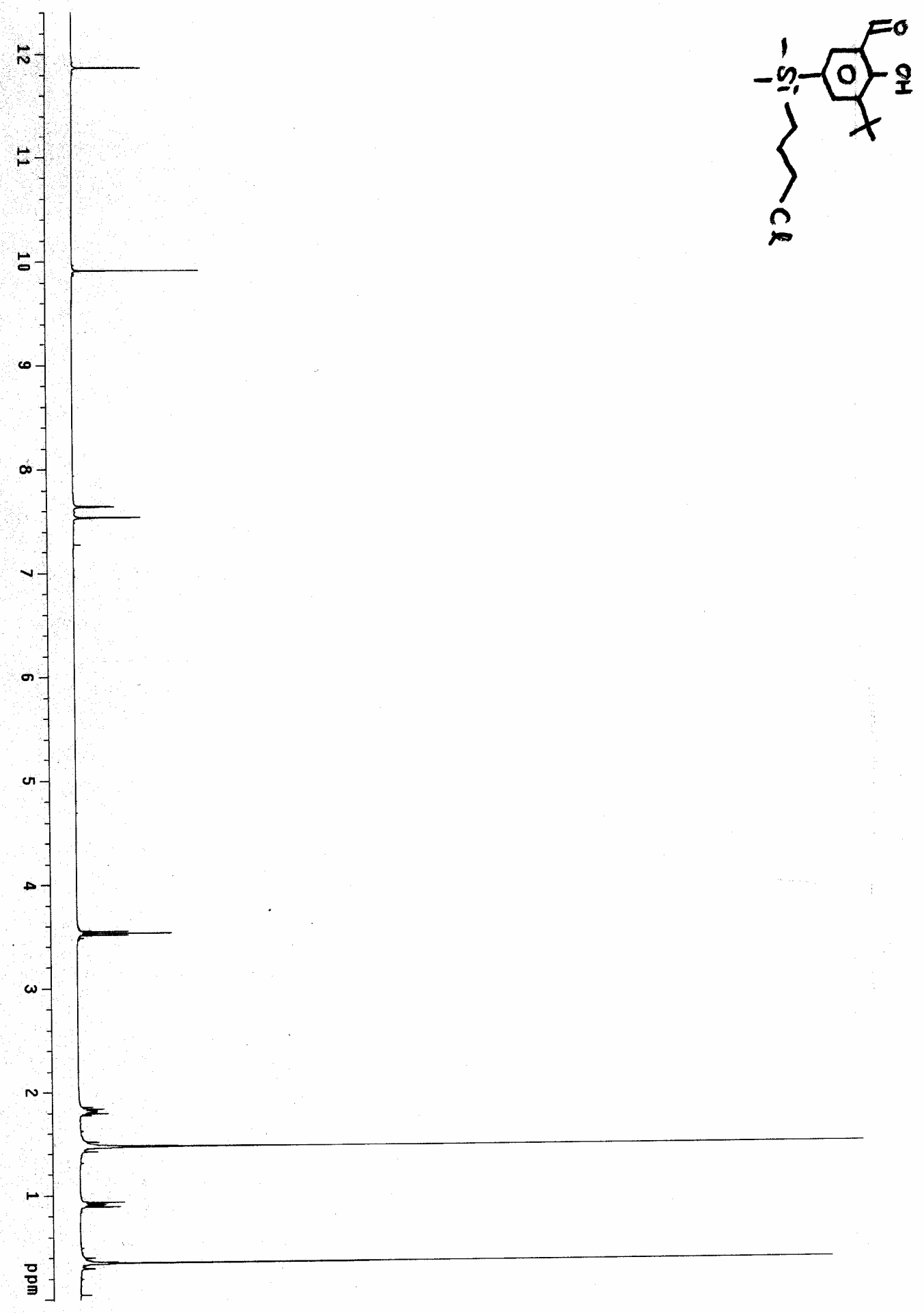


$<{ }^{13} \mathrm{C}$ NMR spectrum of $4>$

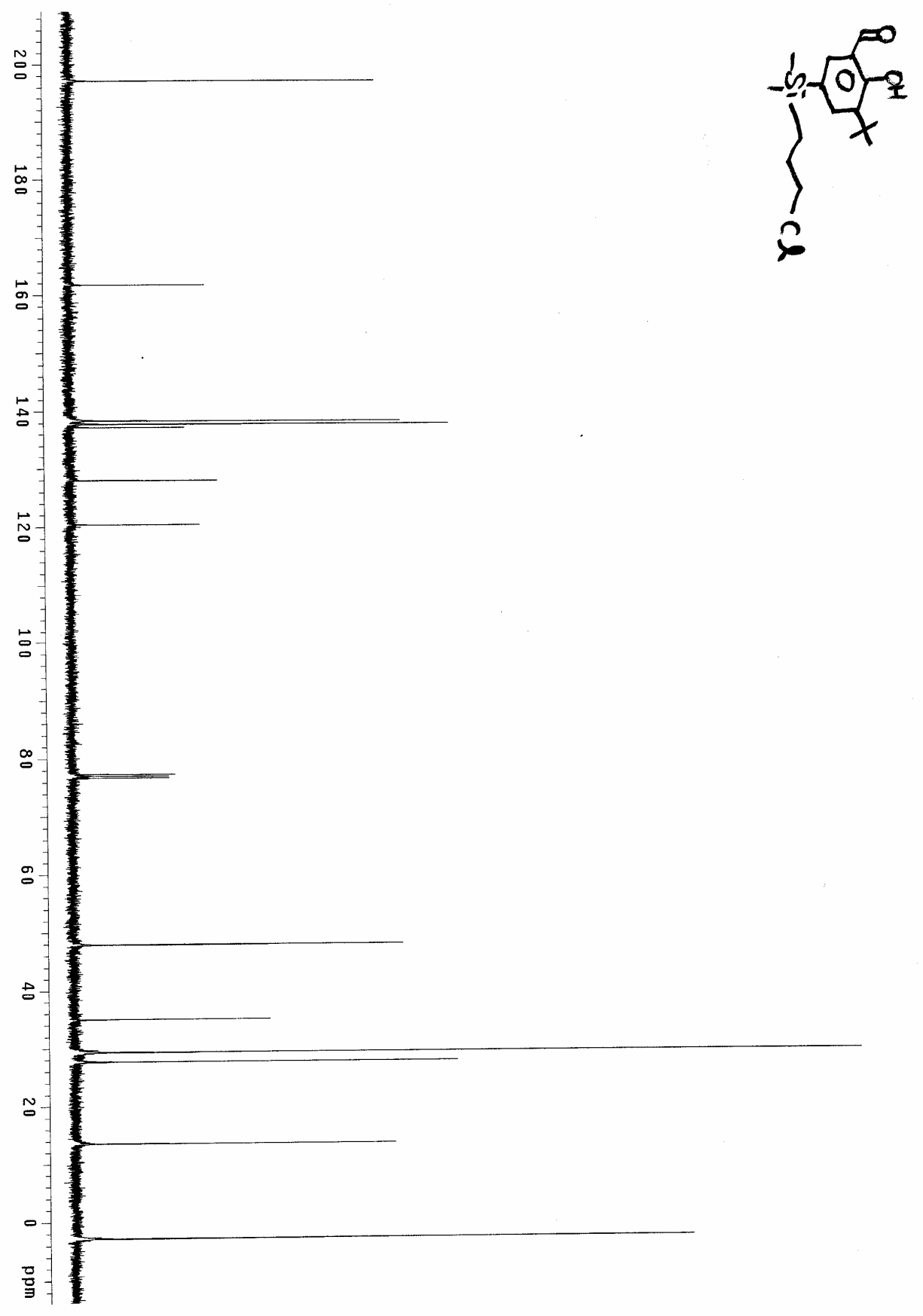


$<^{1}$ H NMR spectrum of 5>

9

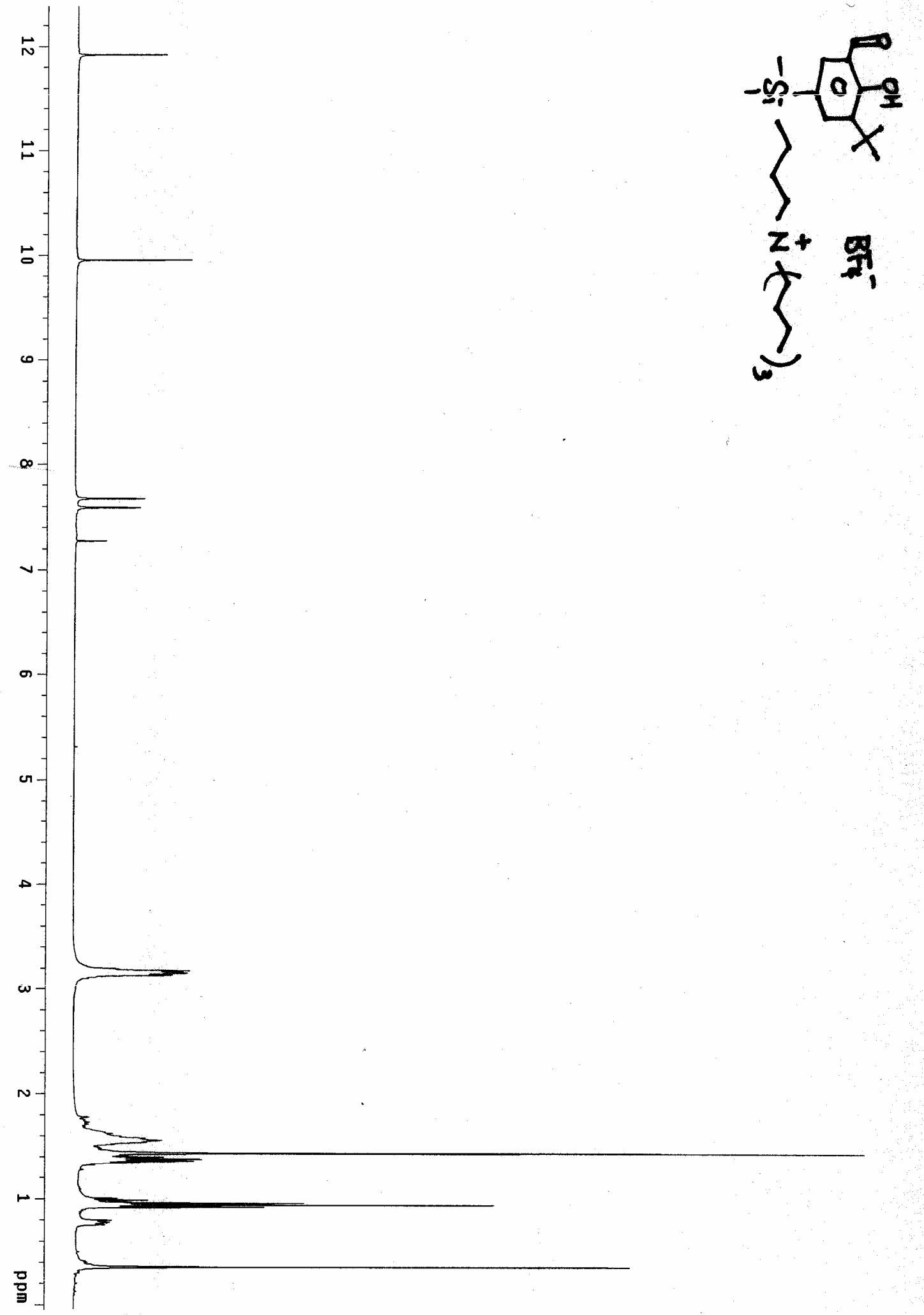


$<{ }^{13}$ C NMR spectrum of 5>

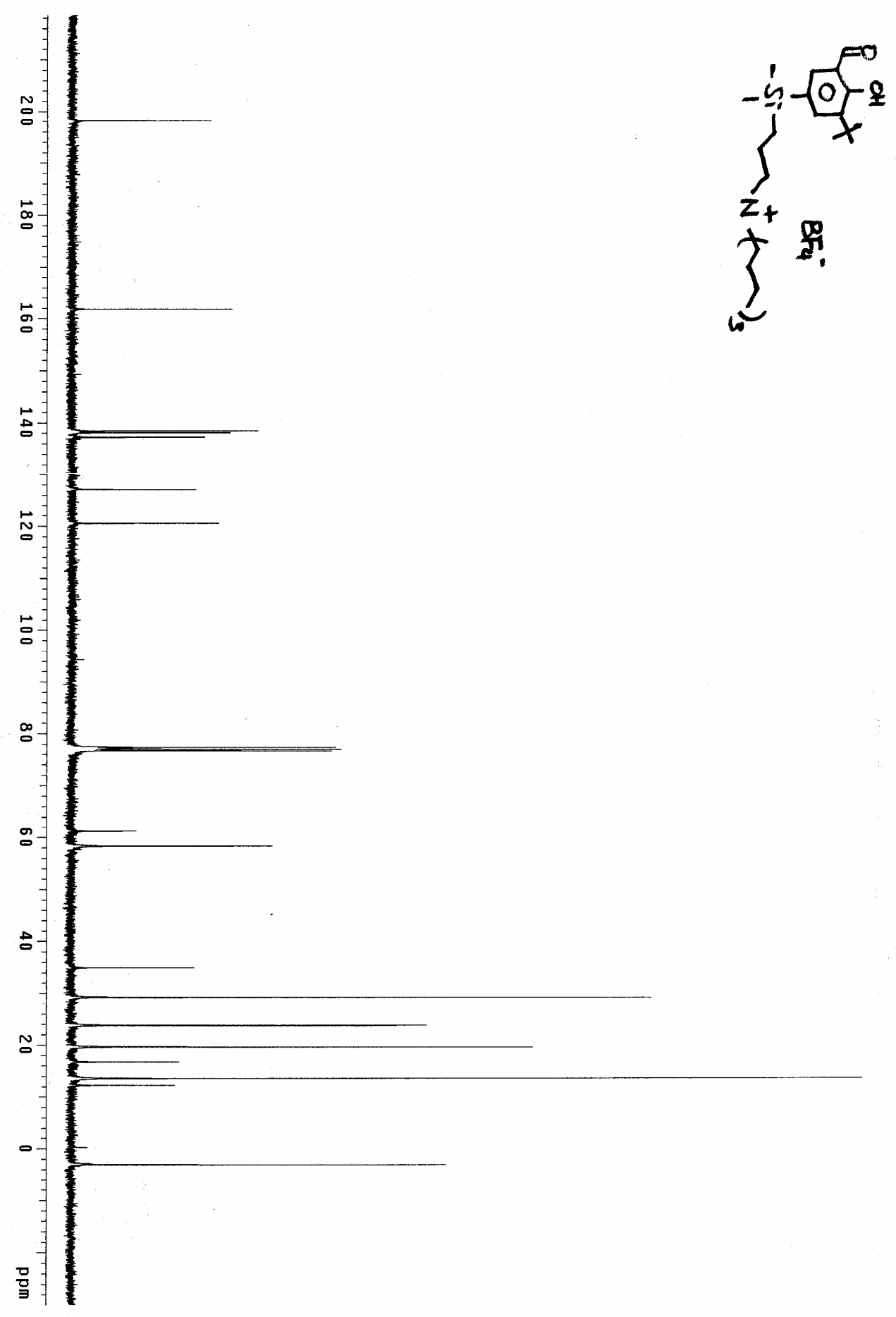


$<{ }^{1}$ H NMR spectrum of the ligand of $1>$

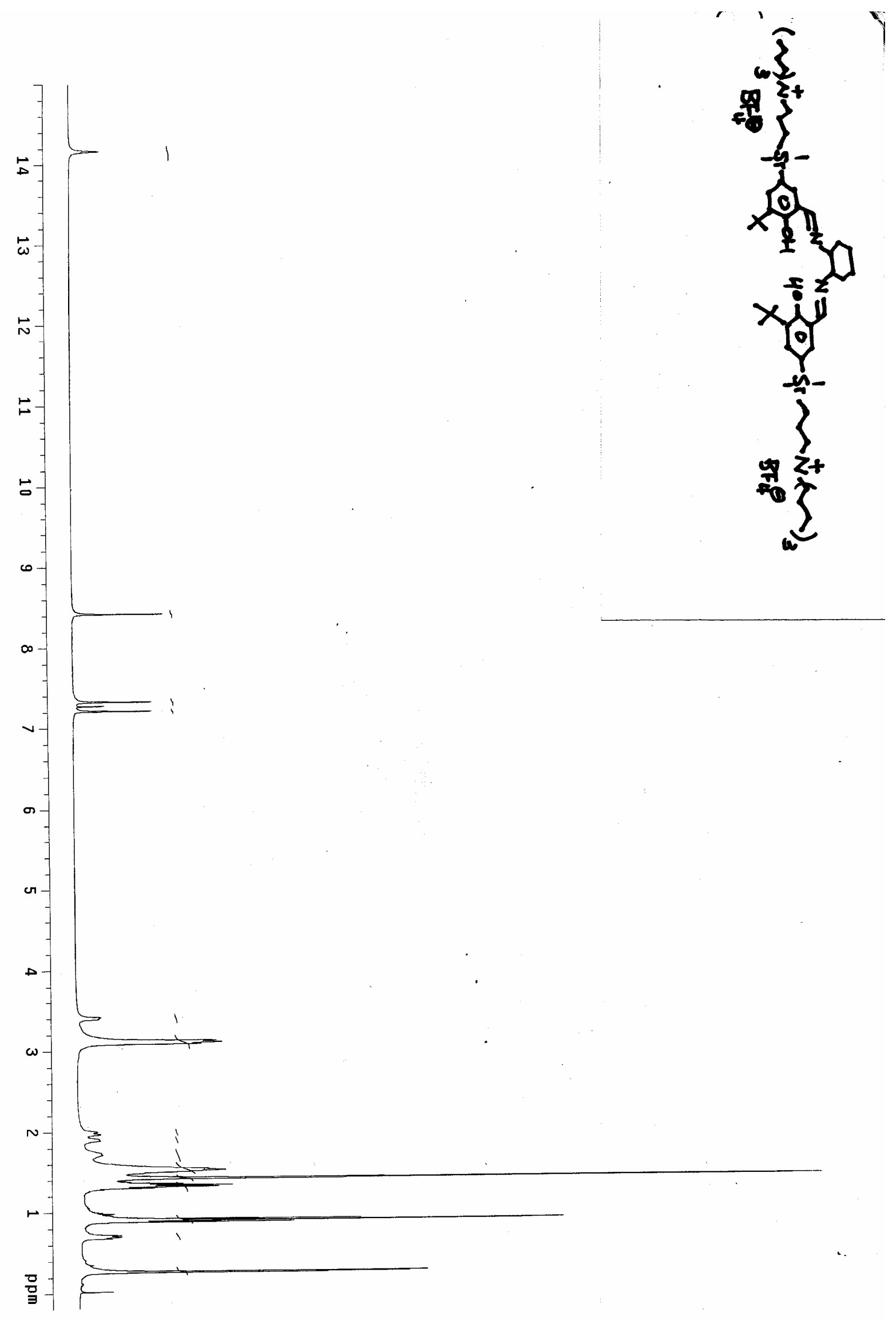


$\left\langle{ }^{13} \mathrm{C}\right.$ NMR spectrum of the ligand of $1>$

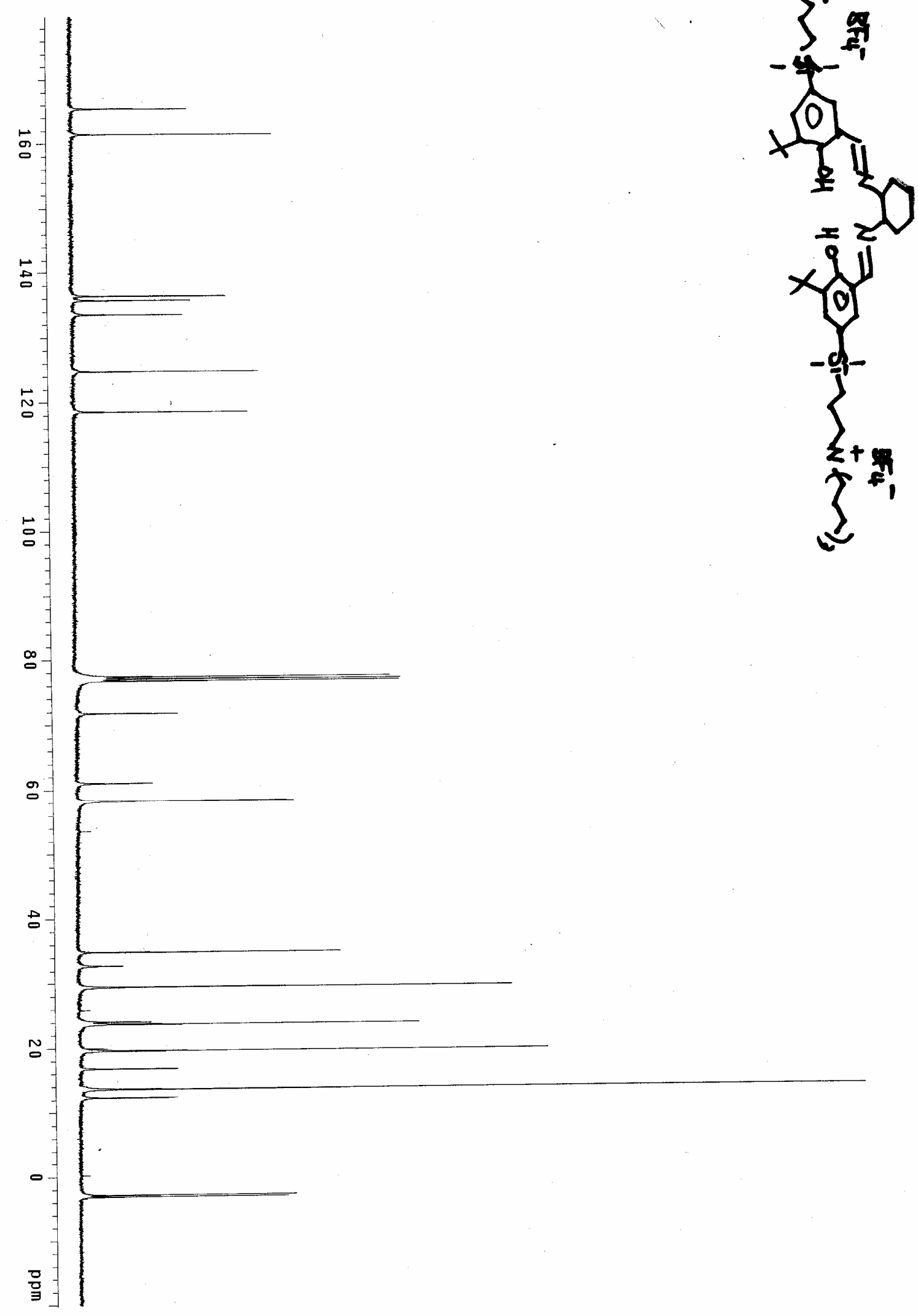


$<^{1}$ H NMR spectrum of $1>$

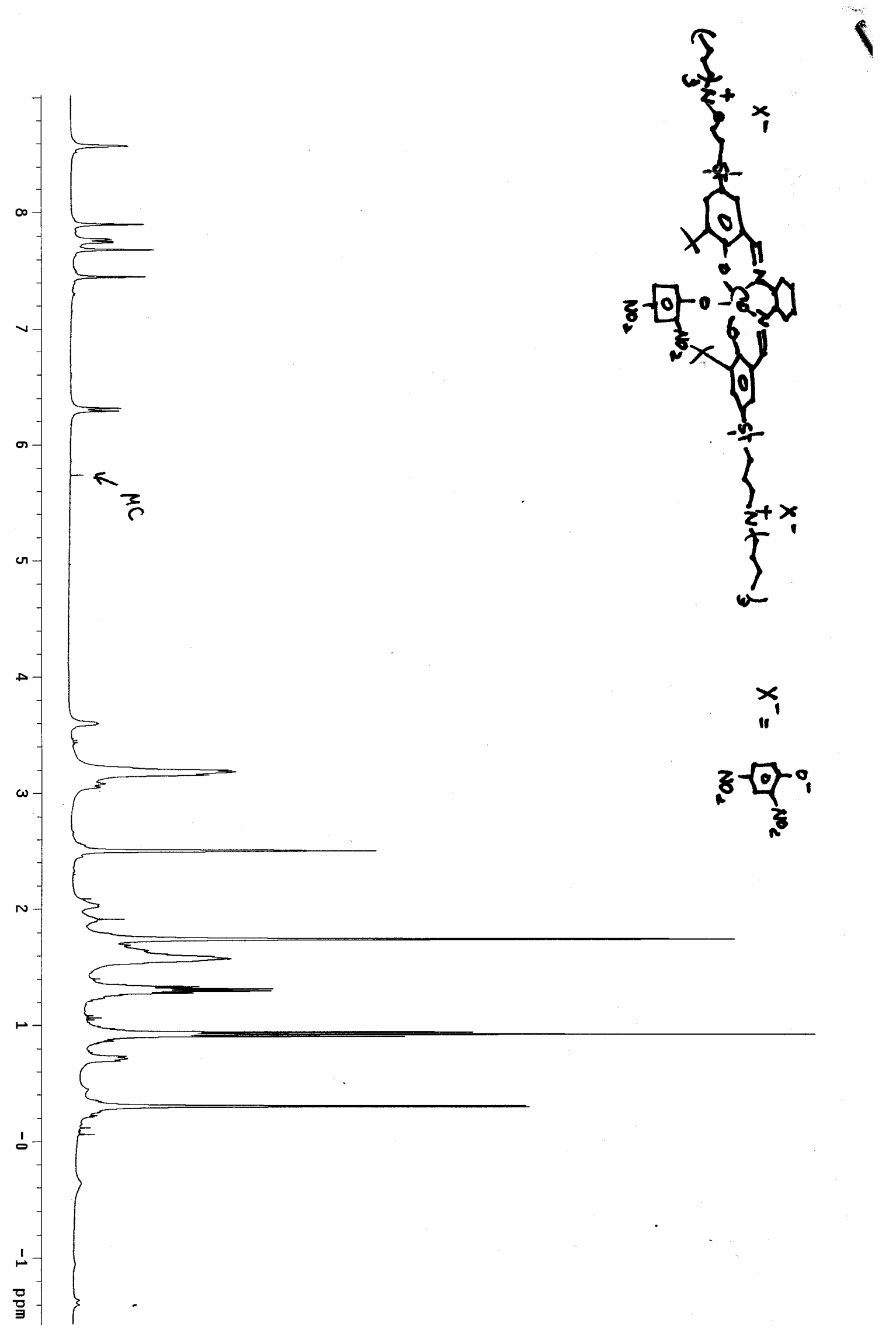


$<{ }^{13}$ C NMR spectrum of $1>$

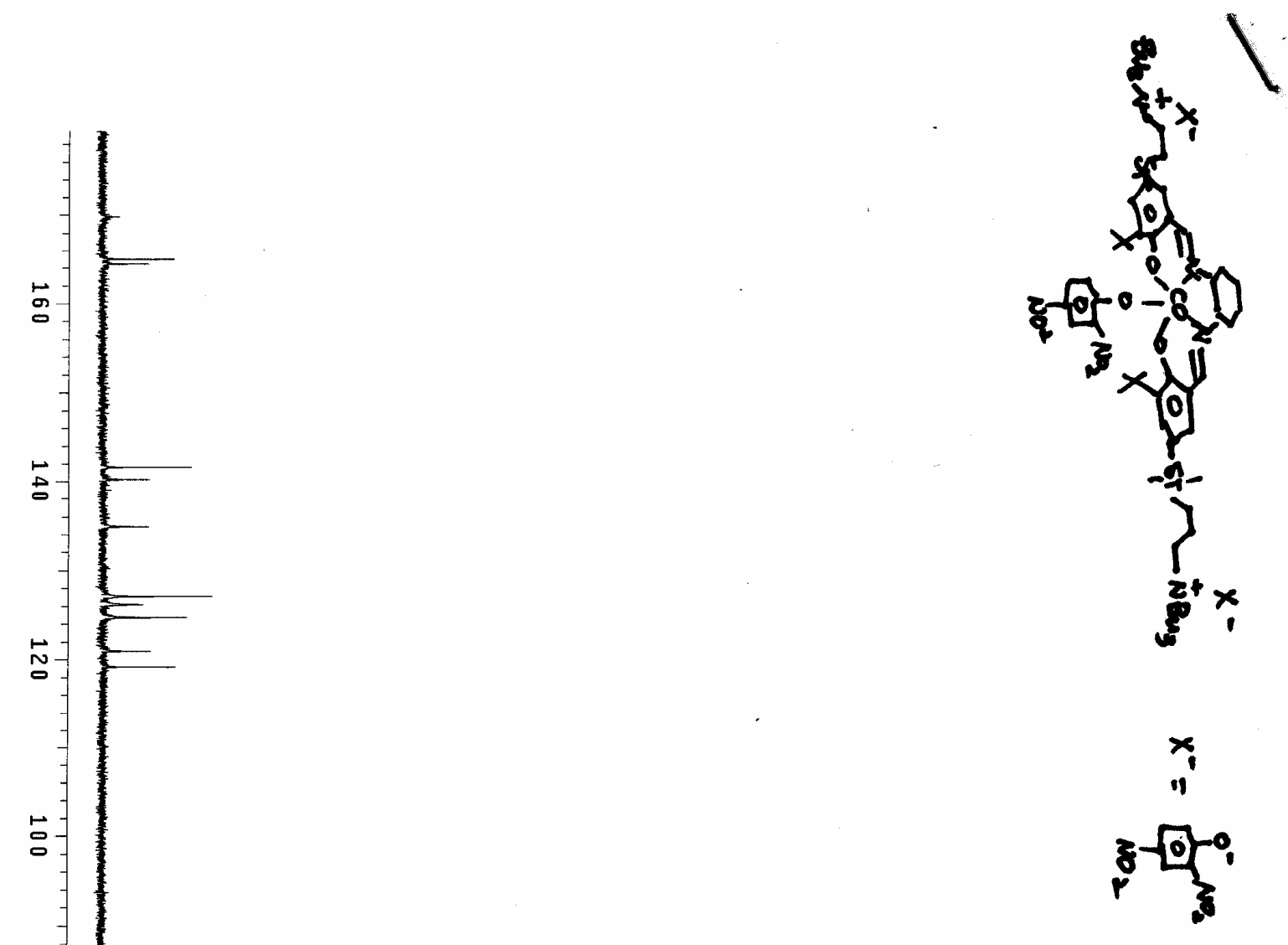

$\stackrel{\infty}{\circ}$

g

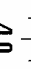
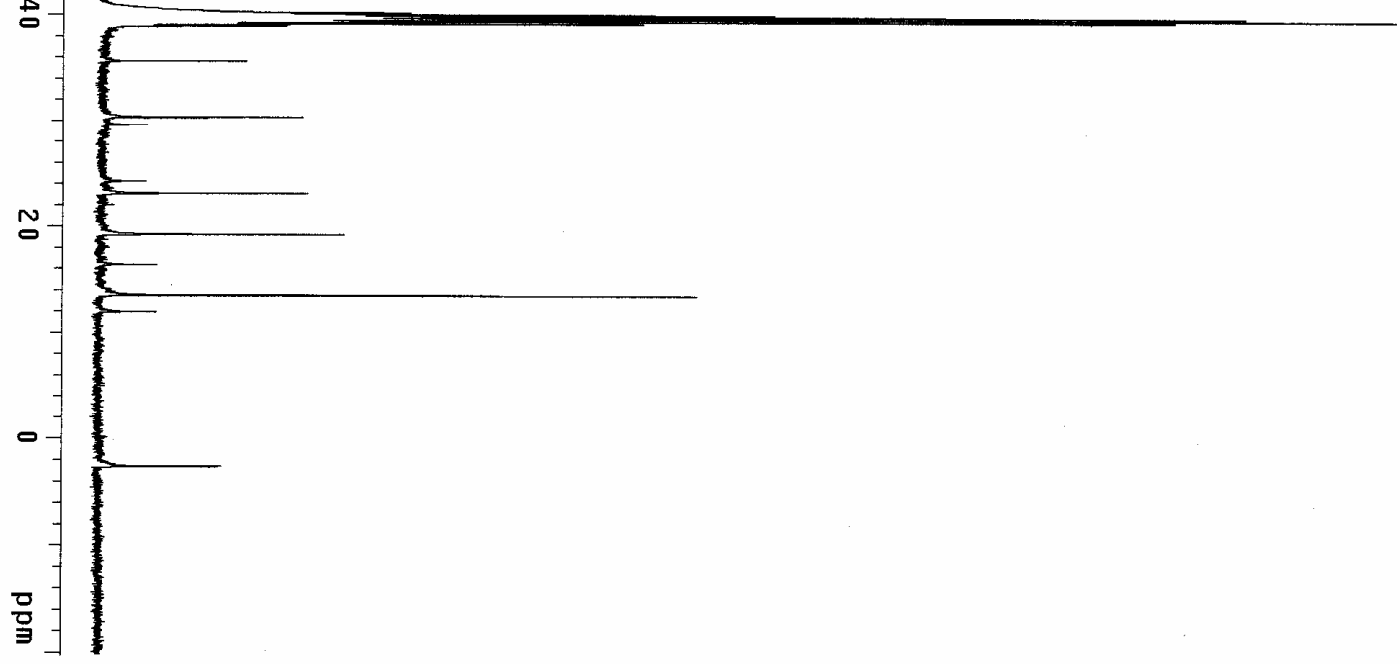